\title{
What drives Tadawul All Stock Index of the Saudi Stock Market?
}

\author{
Khalafalla Ahmed Mohamed Arabi \\ College of Administrative and Financial Sciences \\ King Khalid University
}

\begin{abstract}
This paper aims to detect factors, which drive Tadawul All Stock Index (TASI) of the Saudi Stock Market during the period August 2005 May 2017. The application of Autoregressive Distributed Lag model (ARDL) and Bounds test revealed that there is no long-run relationship exist if consumer price index, interest rate, oil prices, general price level (P) and government expenditure are included in the model. While priceearnings ratio, nominal effective exchange rate (NEER), money supply (M3), and long term credit (L) relate significantly to TASI in both the short-run and long-run with an error correction term $\mathbf{- 0 . 2 2}$ i.e. disequilibrium takes four and half month to correct. Half of explanatory variables are fixed namely NEER, and L, while PE and M3 are dynamic. The GARCH model presented that news plays significant role in the volatility of stock market returns. Smaller GARCH term than ARCH indicates that a shock will take short time to die out.
\end{abstract}

Key Words: ARDL, dynamic, fixed, GARCH, News, shock, volatility

\section{INTRODUCTION}

Stock markets play an unequivocal role in the economic activity serving as a mediator between lenders and borrowers. Stock prices are affected by expected returns and the discount rate which in turn influenced by macroeconomic variables (Kalyanraman and Tuwajin 2014). There two views referring to the relationship between stock market and macroeconomic variables, i.e. stock market is an indicator of economic activity if future performance of corporate and profits are reflected in prices, however the second one assumes the opposite, the stock market affects economic activity via aggregate consumption and investment (Ahmed 2008, Thaker 2009). Understanding the relationship macroeconomic variables and the stock market makes the government capable of stabilizing the stock market and the economy as a whole which attract investors and firms (Barakat, Algazzar and Hanafy 2016).

The trading shares of Arabian Cement, the National Bank, Riyad Bank and the Dutch Bank founded on supply and demand without any official censorship or supervision before 1980's was the starting point toward full-fledged Stock market. The number of companies increased with time to inspire the government to form a joint committee from Ministry of Finance and National Economy and Saudi Monitory Authority (SAMA) in 1984 to be responsible for organizing and monitoring the stock trading. A year later SAMA became the only supervisor, and in 2003 the Capital Market Authority 'was established (Jarrah and Saleem 2016). The introduction of the first electronic trading system integrated for settlement and clearing was in 1990. Saudi Stock Exchange (KSE) is ranked as the second largest in Gulf Cooperative Council (GCC) in terms of market size. Listed comprises dealing in free floating shares that determine TASI performance are 163.

Many empirical researches identified factors manipulating the behaviour of Tadawul All Stock Index and recognized different sets of variables. The aim of this research is to answer the following question: what drives TASI of the Saudi Stock Exchange? 
This research differs from others in terms of estimation method, where autoregressive distributed lag model is estimated as an appropriate model for mixture of integrated variables of order I(0) and I(1) as has been proven by Peseran and Shen (1997).

This research is organized as follows: introductory section precedes previous studies followed by conceptual framework, methodology, results, discussion, and conclusion.

\section{PREVIOUS STUDIES}

There is a vast literature on the determinants of the developed and emerging Stock markets. The number of Stock prices determinants varies from one to nine. Empirical research on Gulf Cooperative Council stock markets including Saudi Arabia established significant effects of two sets of macroeconomic variables on all stocks indices. The first commonly used set is composed of oil prices, money supply, and inflation, while the second set appeared in some studies comprises interest rate, exports, government expenditure, exchange rate, global stock prices, price - earnings ratio, and industrial production index.

Alshogeathry (1998) employed VECM and GARCH to recognize the impact of narrow and broad money supply M1, M2, interest, inflation, bank credit, oil prices, nominal effective exchange rate, NEER, and Standard and Poor index on TASI; Aroura et al. (2011). The study supported the long-run and short-run relationship between oil prices and the stock market in GCC. The study of Mgammal (2012) on KSA and UAE verified the impact of inflation, interest rate, and exchange rate on the general index. Samontaray et al (2014) employed step-wise regression and correlation analysis to recognize only three factors viz. oil (West Texas Light), priceearnings ratio, and exports. Kalyanaraman and Al-Tuwajri (2014) used vector error correction model to study the impact of five macroeconomic variables on TASI to find a significant impact of consumer price index, industrial output, money supply, exchange rate and oil prices.. Kalyanaraman (2015) used vector error correction model to estimate the impact of inflation, industrial production, money supply, exchange rate, oil prices and global stock prices on the returns of 15 listed sectors on the Saudi stock market. Al-Mutairy and Al-Omer (2006) utilized vector autoregression technique to study the impact of interest rate, money supply, inflation, and government expenditure on traded shares in Kuwait Stock market; oil prices and economic variables Fundamentals Jarrah and Salim (2016) analyzed Aljazira report that contains internal and external news and events on 13 sectors of Tadawul i.e. oil prices, company news and industry performance, performance and investors sentiment, economic outlook, inflation, deflation, changing in economic policy, and the value of US dollar

Ahmed (2008) employing Bayesian Vector Autoregression investigated the causal relationship between stock prices and key macroeconomic variables namely the index of industrial production, exports, foreign direct investment, money supply, exchange rate, interest rate, NSE Ninfty and SE Sensex in India. Thaker, et al. (2009), used error correction model to identify the effects of money supply M2, inflation, and nominal effective exchange rate NEER in Malaysia. Eryigit (2012) verified via vector autoregression the dynamic relationship between interest rates, exchange rates, oil prices and Istanbul index; Ahmad et al. (2015) found that per capita GDP, gross domestic saving GDS, foreign direct investment (FDI), Inflation, interest rate, nominal effective exchange rate NEER, M2 have an impact on global index in Nigeria, Barakat et al. (2016) utilized causality and cointegration methods to establish long-run relationship among consumer price index (CPI), exchange rate, M2, interest rate in emerging markets: Egypt and Tunisia. Kasman (2003),Tabak (2006), Sifunjo (2012) and Al-Daham (2017) empirically supported the cointegration relationship between exchange rate and stock prices and causality (exchange rates cause stock prices) in Kenya, Turkey, Brazil and six GCC respectively contrary to Amarasinghe (2014) results on Sri Lankan index, while Kutty (2010) 
showed that stock prices in Mexico lead exchange rate and there is no long-run relationship between the two variables. Širǔcek (2013) confirmed via Granger test the effect of the change of the money supply on the development of the Dow Jones Industrial Average (DJIA) index

\section{Money Supply:}

\section{CONCEPTUAL FRAMEWORK}

Changes in money supply through Treasury Bills change interest rates leading to alterations in mortgage rate and home affordability. Then shifts in the demand for durable goods are inevitable and ultimately the attraction of investments in stocks Hunkar Ozyasar (2013). Veselá (2007) perceives that money supply is the predicting indicator of the development of equity prices. Efficient market hypothesis postulates that stock prices incorporate all relevant information; while monetary market hypothesis expects an increase in money supply will result in an increase in almost all economic activities including the stock market (Friedman 1988). Fama (1981) expects negative impact of an increase in money supply is possible if it results caused inflationary pressures. Tobin's q ratio hypothesizes that the purchases of new investment goods lead to new issuance of stock at higher prices, and raise production and viceversa.

\section{Nominal Effective Exchange Rate NEER:}

Exchange rate fluctuations are the transmission channel that affects firms' value through changes in competitiveness and value of assets and liabilities dominated in foreign currency, ultimately affecting their profits and therefore the value of their equity (Ahmad et. al. 2015). Stock prices may affect exchange rate via inflows/outflows of foreign capital (Thaker, et al. 2009).

\section{Real GDP:}

High economic growth creates demand for financial instruments and thereby financial markets are effectively responding to these demands and change (Choong et al. 2003). Stock market can affect economic growth through channeling saving and investment, improvement of capital productivity, and efficient allocation of resources. If the economy is expected to expand investors buy shares in prospects of future profits and vice- versa (Jarrah and Salim 2016).

\section{General Price Level:}

Higher prices lead to higher interest rate bringing stock prices down, on the contrary deflation lowers profits and decreases economic activity, investors begin selling their shares and invest in real assets tending to go down (Alsogeathry 1998, Jarrah and Salim 2016). Inflation influence on stock prices may be positive if stock prices looked at claims on real resources or negative due the adverse effect on real activity and consequently stocks (Fama 1981).

\section{Price-Earnings Ratio:}

The release of favourable financial reports specifically the ratio of price to earnings, raises investor's optimism and the likelihood of profits, stock demand will ascent and so will its price, on the other hand negative report causes stock price to fall. High price-earnings ratio may point toward overvaluation of stock while low one indicates undervaluation (Motley Fool 2016).

\section{Bank Credit:}

Changes in money supply and credit aggregates have been observed to be associated with stock prices Kindleberger (1978).The asymmetry of information leads to a deterioration of bank loan quality as a consequence of over-optimism and relaxation of loan rule at the time of 
economic expansion. This is in line with Kiyotaki and Moore (1997) who postulate that equity serves as a guarantee for lending and investment, which ultimately affect the stock prices.

\section{Methodology and Data}

\section{METHODOLOGY, DATA, AND EMPIRICAL RESULTS}

ARDL cointegration technique is preferable when dealing with variables that are integrated of different order, I(0), I(1) or combination of both and, robust when there is a single long-run relationship between the underlying variables in a small sample size (Nkoro \& Uko 2016). The ARDL approach can be applied regardless of whether the underlying regressors are integrated of order one [I(1)], order zero [I(0)] or fractionally integrated (Odhiambo 2010). An autoregressive distributed lag model ARDL is a least squares regression containing lags of the dependent and explanatory variables. Pesaran and Shin (1997) showed that if variable are I(1) the OLS estimator of the short-run parameters are $\sqrt{T}$ consistent and the long-run are superconsistent. The variables in the cointegrating relationship can be either I(0) or I(1), without requiring to pre-specify which are I(0) or I(1) and no need for lag symmetry. ARDL(p,q) is composed of explanatory variables that are

$$
\begin{gathered}
y_{t}=\alpha_{0}+\alpha_{1} t+\sum_{i=1}^{p} \theta_{i} y_{t-i}+\beta^{\prime} x_{t}+\sum_{i=0}^{q-1} \beta_{i}^{* \prime} \Delta x_{t-i}+\mu_{t} \\
\Delta x_{t}=P_{1} \Delta x_{t-1}+P_{2} \Delta x_{t-2}+\cdots+P_{s} \Delta x_{t-s}+\varepsilon_{s}
\end{gathered}
$$

Where $x_{t}$ is k-dimensional I(1) variables that are not cointegrated among themselves and $\varepsilon_{t}$ and $\mu_{t}$ are serially uncorrelated with zero means and constant-covariances and $\mathrm{P}_{\mathrm{i}}$ are $\mathrm{k} \times \mathrm{k}$ coefficient matrices such that the VAR process in $\Delta x_{t}$ is stable.

\section{Empirical Results}

Description of Variables: according to Bounds test only four variables have been selected. Tadawul All Stocks Index (TASI), nominal effective exchange rate (NEER), and price-earnings ratio (PE) are presented in points, money supply (M3), and long term bank credit (L) are in million Riyals, and all variables are available in web site of the Capital Market Authority for the period August 1997-May 2017. http:/sama.gov.sa/ar-sa/Economic Reports/Pages/Annual Report.aspx

\section{Movements of Tadawul All Stock Index (TASI)}

According to index figures the real commencement of the Saudi market was in early 1994 where the first mounting wave responded to increased capitalization and improvement in the economy after the liberation of Kuwait. The index rose from 1283 to expire at 1958 in 1997. Owing to the economic crisis in East Asia that affected adversely the petrochemical companies, fall of oil prices, lower world prices of cement accompanied by low local demand, and high interest rate in Riyal the index declined to 1413 in 1998 to mark thereafter the second surge that has been ascending to reach the peak of 16713 in 2005 . The prominent events were: big leap in oil prices, opening the door to investment in the Saudi market to foreign investors through local equity funds, amendment of commission, reduction of tariffs on imported goods, payments of farmers and contractors dues, Cabinet allowance of GCC nationals to trade in the shares of banks and insurance, issuance of new regulations by Capital Market Authority (CMA) i.e. securities regulation and the list of authorized persons, and the Kingdom joining to WTO. The third wave was the response to the declaration of minister of finance that the stock prices were overvalued, combined with other factors such as increased political tension in the region that ended in US-Iraq war, the declared intention to sell part of the State shares in joint stock 
companies that led to negative effect on big corporations in the market which causing sharp decline to 7933 points in 2006. In the Fourth wave the index raised to 11039 in 2007 to decline in 2008 to 4803 points (the lowest points in the current decade), then continued climbing up combined with small swings ups and downs till the year 2013 that ended at 8536 points. The fifth wave started from the peak of the fourth session to show downward trend owing to reduction in oil prices and Yemen war.

\section{Diagnostic Tests}

The noticeable features of annex (1) are lack of normality at both the level and natural logarithm of the model variables; price-earnings ratio (PE) is the most dispersed variable, while NEER is the least one.

Unit roots tests have been run for level and natural logarithm of the model variables to ensure that none of the variable is integrated of order two or over. Results displayed in table (1) below illustrate that all variables are integrated of order one at $1 \%$ level of significance except PE which is stationary at $5 \%$ and $1 \%$ for the level and logarithmic form as quantified by ADF\& PP tests respectively.

Table (1) Unit Root Test Results

\begin{tabular}{|l|c|c|c|c|}
\hline & \multicolumn{2}{|c|}{ Augmented Dickey-Fuller } & \multicolumn{2}{|c|}{ Phillips-Peron } \\
\hline Variable & Level & Ist. Diff. & Level & Ist. Diff. \\
\hline INDEX & -1.959 & $-12.453^{* * *}$ & -1.991 & $-12.469^{* * *}$ \\
\hline LOG(INDEX) & -1.691 & $-12.533^{* * *}$ & -1.634 & $-12.725^{* * *}$ \\
\hline M3 & -1.689 & $-7.644^{* * *}$ & 1.869 & $-17.854^{* * *}$ \\
\hline LOG(M3) & -0.114 & $-16.817^{* * *}$ & -0.128 & $-16.798^{* * *}$ \\
\hline NEER & -1.847 & $-11.000^{* * *}$ & -1.779 & $-11.000^{* * *}$ \\
\hline LOG(NEER) & -1.864 & $-11.038^{* * *}$ & -1.851 & $-11.097^{* * *}$ \\
\hline PE & $-3.299^{* *}$ & & $-3.233^{* * *}$ & $-5.257^{* * *}$ \\
\hline LOG(PE) & $-3.126^{* * *}$ & & $-3.073^{* * *}$ & \\
\hline L & 1.599 & $-5.451^{* * *}$ & 1.717 & $-20.056^{* * *}$ \\
\hline LOG(L) & -2.398 & $-17.644^{* * *}$ & $-2.608^{*}$ & $-17.497^{* * *}$ \\
\hline
\end{tabular}

$\left({ }^{*}\right)\left({ }^{* *}\right)\left({ }^{* * *}\right)$ indicates rejection of null hypothesis of unit root at $10 \%, 5 \%$, and $1 \%$

The long-run relationship between model variables has been explored by Johansen System Cointegration test to detect 3 cointegration equations at $5 \%$ as presented in table (2). 
Table (2) Cointegration Results

Date: 08/29/17 Time: 17:03

Sample (adjusted): 2006M01 2017M05

Included observations: 137 after adjustments

Trend assumption: Linear deterministic trend

Series: LOG(INDEX) LOG(M) LOG(PE) LOG(L) LOG(NEER)

Lags interval (in first differences): 1 to 4

Unrestricted Cointegration Rank Test (Trace)

Hypothesized

No. of CE(s)

None ${ }^{*}$

At most 1 *

At most 2 *

At most 3

At most 4

Eigenvalue
0.238427
0.160665
0.143766
0.057634
0.005277

\begin{tabular}{|l|l|} 
& Trace \\
\hline & \\
\hline & \\
\hline & \\
\hline
\end{tabular}

Trace

Statistic

91.43081

54.11617

30.12129

8.857296

0.72482

\begin{tabular}{|c|c} 
& \\
\hline & 0.05 \\
& 6 Critical Value \\
\hline 6.81889 \\
\hline 47.85613 \\
\hline 29.79707 \\
15.49471 \\
\hline 3.841466 \\
\hline
\end{tabular}

0.05

Trace test indicates 3 cointegrating equation(s) at the 0.05 level

* denotes rejection of the hypothesis at the 0.05 level

**MacKinnon-Haug-Michelis (1999) p-values

\section{Estimation Results}

However the established long-run relationship between model variables which are a mixture of I(0) and I(1) involves electing an appropriate model which in this situation is the ARDL.

Table (3) ARDL Results

\begin{tabular}{|l|c|c|}
\hline \multicolumn{2}{|c|}{ Short Run Coefficients } \\
\hline & Level & Logarithm \\
\hline Variable & Coefficient & Coefficient \\
\hline DLOG(M3) & $0.004963^{* *}$ & $0.617252^{* * *}$ \\
\hline DLOG(NEER) & $-30.429^{* *}$ & $-0.45713^{* * *}$ \\
\hline DLOG(PE) & $78.376^{* * *}$ & $0.390678^{* * *}$ \\
\hline DLOG(L) & $0.006078^{* *}$ & $0.218193^{* * *}$ \\
\hline CointEq(-1) & $-0.1733^{* * *}$ & $-0.22029^{* * *}$ \\
\hline & Coefficient & Coefficient \\
\hline Variable & $-0.00611^{*}$ & $-0.67582^{* * *}$ \\
\hline LOG(M3) & $-175.591^{* *}$ & $-2.07512^{* * *}$ \\
\hline LOG(NEER) & $146.4977^{* * *}$ & $0.568777^{* * *}$ \\
\hline LOG(PE) & $0.035075^{* * *}$ & $0.990479^{* * *}$ \\
\hline LOG(L) & $22112.06^{* * *}$ & $14.18386^{* * *}$ \\
\hline C & 15.766 & -2.859 \\
\hline Akaiki Information Criteria & 15.933 & -2.691 \\
\hline Schwarz Information Criteria & & $2.45<3.154<3.52$ \\
\hline Bounds Test & $1.826>2.45$ & $\mathbf{5}$ \\
\hline
\end{tabular}

$\left({ }^{*}\right)\left({ }^{* *}\right)\left({ }^{* *}\right)$ indicates rejection of null hypothesis of unit root at $10 \%, 5 \%$, and $1 \%$

According to Akaiki and Schwarz information criteria the logarithmic form is favorite to the level, in addition the null hypothesis of the bounds test that no long-run relationship exists for the level model are accepted since the test statistic is less than the lower bound, and they are inconclusive for the logarithmic one, therefore the second model outweighs the first. The estimated coefficient got the expected signs. Money supply affects stock prices positively in the short run and negatively in the long run. Price-earnings ratio, long term credit influence stock 
prices positively in the short and long run. NEER has adverse effects on stock prices in the short-run and long-run. All estimated coefficients of the second model are significant at 1\%, while the significance of first model varies from $10 \%$ to $1 \%$. The number of variable contained by the second model is adequate as Ramsey RESET Test $\left(F_{1,132}=0.226\right.$, Prob. 0.635$)$ shows. The second model does not suffer from first order autocorrelation (DW=2.04) or second order $\left(F_{2,131}=0.235\right.$, Prob. 0.791$)$, while the hypothesis of homoscedasticity $\left(F_{7,133}=\right.$ 4.180, Prob. 0.000), and no ARCH effect $\left(F_{1,28}=8.437\right.$, Prob. 0.002$)$ are rejected despite this weakness the model forecast traces the original data as depicted by the historical simulation figure (1) where Theil inequality coefficient is 0.04 , bias proportion 0.015 , variance proportion 0.147 , and covariance proportion 0.838 . About 0.173 and 0.22 of the disequilibrium corrected each month in first and second model respectively. The speed of adjustment of the first model takes approximately six months while second takes about four and half months to correct.

Figure (1) Historical Simulation

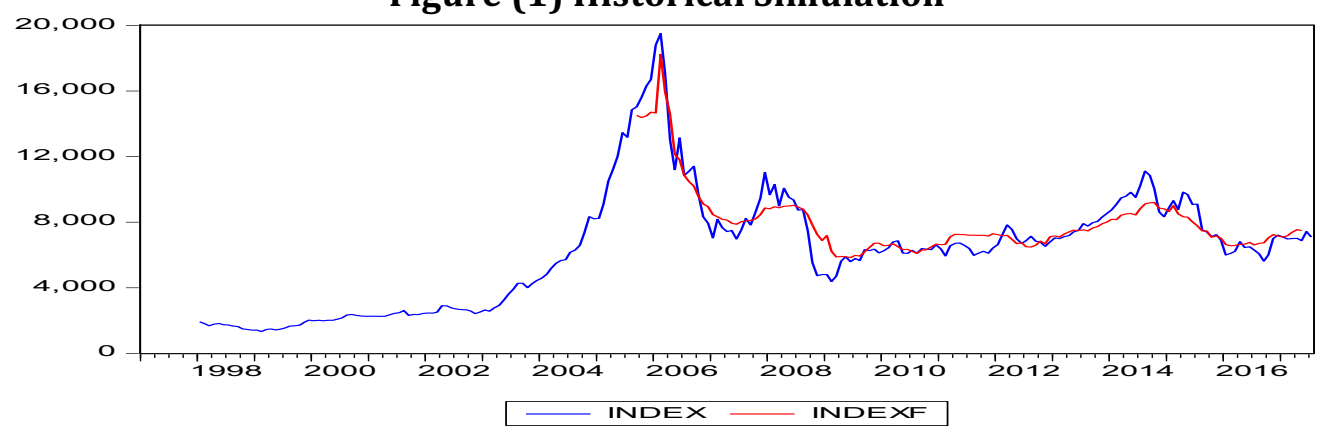

The role of news was investigated through GARCH model at both the level and logarithmic form as table (4) shows. The estimated model at the level presents insignificant coefficients of bank credit and NEER, while all the coefficients of logarithmic form are significant at $1 \%$. Therefore the second model is far better than the level in terms of significance of estimated coefficients, and $\mathrm{R}$ squared. The correction of autocorrelation has been done by moving average MA(1). ARCH-LM test accepts the null hypothesis of homoscedasticity, Ljung-Box $\mathrm{Q}, \mathrm{Q}^{2}$ statistics ascertain the stationarity of the second model residuals. The ARCH term is positive and greater than the GARCH denotes that bad news affects the stock market volatility and previous asset prices have insignificant effect. The sum of ARCH \& GARCH terms is .981 point out that GARCH model is covariance stationary (Nelson 1990). The lesser GARCH term is indicating that a shock will take short time to die out so volatility is not persistent. 
Table (4) GARCH Results

\begin{tabular}{|l|c|c|}
\hline & Level & Logarithm \\
\hline Variable & Coefficient & Coefficient \\
\hline M3 & $0.003547^{* * *}$ & $-0.64093^{* * *}$ \\
\hline L & 0.001779 & $0.635989^{* * *}$ \\
\hline PE & $203.7446^{* * *}$ & $0.944861^{* * *}$ \\
\hline NEER & -8.26953 & $-1.9797^{* * *}$ \\
\hline MA(1) & $0.679839^{* * *}$ & $13.64842^{* * *}$ \\
\hline \multicolumn{2}{|c|}{ Variance Equation } \\
\hline C & $6630.099^{* * *}$ & $0.001223^{* * *}$ \\
\hline RESID(-1)^2 & $0.483604^{* * *}$ & $0.657135^{* * *}$ \\
\hline GARCH(-1) & $0.57547^{* * *}$ & $0.324827^{* * *}$ \\
\hline R-squared & 0.70123 & 0.913224 \\
\hline Adjusted R-squared & 0.692507 & 0.910034 \\
\hline Akaiki Information Criteria & 16 & -2.233 \\
\hline Schwarz Information Criteria & 16.17 & -2.045 \\
\hline
\end{tabular}

$\left(^{*}\right)\left({ }^{* *}\right)\left({ }^{* * *}\right)$ indicates rejection of null hypothesis of unit root at $10 \%, 5 \%$, and $1 \%$

\section{DISCUSSION}

The understanding of the relationship between the index and influencing factors is important to investors, the public, and policy makers. The monitory and fiscal policies influence on share prices run directly through the control of money supply, sale of government shares, commission, and indirectly via lending by manipulating the interest rate, however the link between the stock market and the rest of world is reflected by nominal effective exchange rate. The negative sign of the money supply in the long-run should alert the government about inflationary pressures. Nominal effective exchange rate has adverse effects in the short-run and long-run affecting adversely profits and therefore the value of equity also via inflows/outflows of foreign capital. Release of favorite price-earnings ratio induces investors to purchase such shares so positive sign is in line with axiom. Long term credit is affecting stock prices positively as equity serves as a guarantee for lending and investment which ultimately affect the stock prices. The estimated model traces the historical data closely particularly turning points. About 22 percent of the disequilibrium corrected each month i.e. four and half months.

The efficiency of the Saudi stock market has been tested by the runs and variance ratio tests to yield contradicting results. The run test rejected the randomness hypothesis by the mean and median cut point while accepting it by mode. The variance ratio test accepted the random walk hypothesis. The joint null hypothesis for all periods showed that the Chow-Denning maximum $|z|$ statistic of 1.792883 is associated with the period 8 individual test. The approximate pvalue of 0.2615 accepts the null of a random walk and so do the individual period's tests. Results of GARCH model disclose that bad news has profound influence on the stock market than good news.

\section{CONCLUSION}

The effect of macroeconomic economic variables on stock prices has been empirically determined for developed and emerging market. This paper aimed at recognizing the influential economic variables on Tadawul All Stock Index. Four variables were selected namely price-earnings ratio, money supply, nominal effective exchange rate, and long term credit. All the variables are nonstationary and attain stationarity after the first difference except the stationary price-earnings ratio. Cointegration analysis detected three cointegrating equations establishing long-run relationship among variables. Different analytical tools i.e. 
autoregressive distributed lag model and GARCH has been used to identify factors influence and news respectively. Detected factors belong to economy conditions, and industry conditions namely money supply (M3), long term lending, price-earnings ratio, and nominal effective exchange rate, revealed significant impact, bad news has greater effect than good news, and shocks will take short time to die out so volatility is not persistent.

\section{References}

Abu-Sharia, Rateb Moh'd, Ahmad (2005) Theoretical and Empirical Study of Stock Market Development, Economic Reform and Economic Growth: A Case Study of Arab Countries, unpublished PhD, University of Western Sydney, Australia researchdirect.uws.edu.au/islandora/object/uws\%3A3787/datastream/PDF/view

Ahmad, Ai Umar, Adam Abdullah, Zunaidah Sulong (2015) Causal Relationship between Stock Market and Returns and Macroeconomic Variables in Nigeria Journal of Humanities and social Science Volume 20 Issue 5 PP 74-96. https://pdfs.semanticscholar.org/.../47ca56680dcc579bb1861dc86fc2...

Ahmed, Shahid (2008) Aggregate Economic Variables and Stock Market in India, International Research Journal of Finance and Economics 14, 141-164 www.iosrjournals.org/iosr-jef/papers/vol3-issue6/H0366874.pdf

Al-Daham, Jassim (2017) Relationship between Exchange Rate and Stock Price International Journal of Economics and Financial Issues, 7(2) 11-24 https://ideas.repec.org/a/eco/journ1/2017-02-03.html

Al-Mutairy Abdullah, Kh, and Husain Al-Omer (2006) Macroeconomic Determinants of the Behaviour of Kuwait Stock Exchange Studies in Business and Economics Vol. 13 No.1 PP 39-50 https://mpra.ub.unimuenchen.de/.../1/stock_market_and_macroecon

Alshogeathri, Mofleh Ali Mofleh (1998) Macroeconomic determinants of stock market movement Emprical Evidence from Saudi Stock Market Unpublished PhD Imam Muhammad Ibn Saud Islamic University

https://krex.k-state.edu/dspace/bitstream/handle/2097/.../moflehalshogeathri2011.pdf?

Amarasinghe, AAMD (2014) Dynamic Relationship between Exchange Rate and Stock Returns: Empirical Evidence from Colombo Stock Exchange. International Journal of Liberal Arts and Social Sciences, Vol.2m No. 5 PP 129-137. www.macrothink.org/journal/index.php/ajfa/article/download/.../963.

Arouri Mohamed ElHedi Mondher Belallah and Duc Khuong Nguyen (2011) Further Evidence on Responses of Stock Prices in Gulf Cooperative Council (GCC) Countries to Oil Price Shocks, International journal of business and 16(1)https://www.researchgate.net/.../267369305_Further_Evidence_on_th

Barakat, Mahmoud Ramadan, Sara H. Elgazzar1 \& Khaled M. Hanafy (2016) Impact of Macroeconomic Variables on Stock Markets: Evidence from Emerging Markets, International Journal of Economics and Finance; Vol. 8, No. 1; PP 195-207www.ccsenet.org/journal/index.php/ijef/article/download/.../30012

Choong chee Keong ZulkmainYusop Siong Hook Law nf Khim Venus Sen (2003) Financial Development and Economic Growth in Malaysia: The Stock Market Perspective Economic Working Paper achieve at WUSTL. https://businessperspectives.org/.../imfi_en_2005_04_Choong.pdf

Elbarghouthi Sameer, Qasim Amin, Yassin Mohammad (2012) The Use of Run Test in Amman Stock Exchange International Business Research Volume 5 No. 2 PP 159-172 www.zuj.edu.jo/wp-content/staff-

research/economic/dr.../5.pdf

Eryigit Mehemet (2012) The Dynamic Relationship between Oi Price Socks and Selected Macroeconomic Variables in Turkey Economic Research Volume 25 Number 2 (263-276)

https://pdfs.semanticscholar.org/.../017ae871286d7eaff7b1fc3d9c9c1

Fama (1981) Stock Returns, Real Activity, Inflation and Money American Economic Review Volume 5 PP 115-146 https://www.researchgate.net/...Real_Activity_Inflation_and_Money..

Friedman, M (1988) Money and Stock Market Journal of Political Economy Vol. 96 PP 221-245 https://www.journals.uchicago.edu/doi/abs/10.1086/261534

Hunkar Ozyasar (2013) The Relationship between Money Supply \& Stock Prices, Zacks Investment Research http://finance.zacks.com/relationship-between-money-supply-stock-prices-7764.html

Ibrahima, Mansor H., Mohamed Eskandar Shah (2012) Bank lending, macroeconomic conditions and financial uncertainty: Evidence from Malaysia Review of Development Finance 2, 156-164

https://biblio.ugent.be/publication/8512978/file/8514770.pdf 
Ibrahim Mansor H. (2006) Stock Prices and Bank Loan Dynamics in a Developing Country: The Case of Malaysia, Journal of Applied Economics. Vol IX, No. 1, 71-89

https://www.ucema.edu.ar/publicaciones/.../volume9/ibrahim.pdf

Ibrahim Muazu, and Musah Alhassan (2014) An Econometric Analysis of the impact of Macroeconomic

Fundamentals on Stock Market Return Research in Applied Economics Vol.6 No. 2

www.macrothink.org/journal/index.php/rae/article/download/.../4433

Jarrah Mu'tasim , and Naomi Salim (2016) The Impact of Macroeconomic Factors on Saudi Stock Market (TADAWUL) International Conference on Advances in Big Data Analysis 71-76 worldcompproceedings.com/proc/p2016/ABD3282.pdf

Kalyanaraman Lakshami (2015) Long-run and short-run between Macroeconomic Factors and Return on Sectoral Indices in Saudi Arabia; Empirical Analysis Mediterranean Journal of Social Studies Vol. 6 No.2 https://papers.ssrn.com/sol3/papers.cfm?abstract_id=2575499

Kalyanaraman Lakshami and Basmah Al Tuwajri (2014) Macroeconomic Forces and Stock Price: Some Empirical Evidence from Saudi Arabia, International Journal of Financial Research Vol. 5 No.1 PP 81-92

Kasman Saadet (2003) the Relationship between the Exchange Rate and Stock Prices: A Causality Analysis, Sosyal Bilimlar Dergisi, Silt 5, Sayi 2, PP 70-79_https://papers.ssrn.com/sol3/papers.cfm?abstract_id=2377652

Kiyotaki, N. and J. Moore (1997), “Credit Cycles”, Journal of Political Economy, 105: 211-248 www.nviegi.net/teaching/master/km.pdf

Kutty, Copalan (2010) the Relationship between Exchange Rates and Stock Prices: the Case of Mexico, North American Journal of Finance and Banking Research Vol. 4, No. 4 PP 1-12 https://globip.com/articles/northamerjournal-vol4-article1.pdf

Mgammal, Mahfoudh Hussein Hussein (2012) the Effect of Inflation, Interest Rates and Exchange Rates on Stock Prices Comparative Study Among Two GCC Countries International Journal of Finance and Accounting, 1(6): 179189erepository.uonbi.ac.ke/.../Muchiri_Effect\%200f\%20Inflation\%20A...

Motley Fool (2016) An Investor's Guide to Price to Earnings Ratio https://www.fool.com/knowledge-center/freecash-flow.aspx

Nelson (1990) stationarity and persistence in GARCH model Econometric Theory 6.318-334 citeseerx.ist.psu.edu/viewdoc/download?doi=10.1.1.458.

Nkoro, Emeka and Uko, Aham Kelvin (2016) Autoregressive Distributed Lag (ARDL) cointegration technique application and interpretation Journal of Statistical and Econometric Methods, vol.5, no.4, 63-91

www.mdpi.com/2227-7099/6/1/16/pdf

Odhiambo, Nicholas M (2010) Are Banks And Stock Markets Positively Related? Empirical Evidence from South Africa Journal of Applied Business Research, Vol. 26 No.6 https://www.cluteinstitute.com/ojs/index.php/JABR/article/.../315

Peseran M. Hashem and Yongscheol Shen (1997) An Autoregressive Distributed Lag Modeling Approach to Cointegration Analysis Symposium at Centennial of Ranger Frisch citeseerx.ist.psu.edu/viewdoc/download?doi=10.1.1.153.

Samontary, D.P, Nugali,S, and Sasidhar,B (2014) A Study of the Effects of Macroeconomic Variables on Stock Market: Saudi Perspective International Journal of Financial Research Vol. 5 No. 4 citeseerx.ist.psu.edu/viewdoc/download?doi=10.1.1.153

Sifunjo E. Kisaka, and Anthony Mwasaru (2012) The Causal Relationship between Exchange Rates and Stock Prices in Kenya Research Journal of Finance and Accounting www.iiste.org Vol. 3, No 7 pakacademicsearch.com/.../121-130\%20Vol\%203,\%20No\%207\%20(.

Širǔček, Martin (2013) the Impact of Money Supply on Stock Prices and Stock Bubbles http://www.slu.cz/opf/cz/informace/acta-academica-karviniensia/casopisy-aak/aak-rocnik-20

Tabak Benjamin M. (2006) the Dynamic Relationship between Stock Prices and Exchange Rate: Evidence from Brazil Working Paper Series 124 Central Bank of Brazil https://www.bcb.gov.br/pec/wps/ingl/wps124.pdf

Thaker, Mohamed Asmy Bin Mohd Thas, Wisam Rohilina, Aris Hassama, and Md. Fouad Bin Amin (2009) Effect of Macroeconomic Variables on Stock Prices in Malaysia: An Approach of Error Correction Model, Munich Personal Re PEc Archive MRPA https://ideas.repec.org/a/hur/ijaraf/v3y2013i2p32-43.html

VESELÁ, J., 2007. Investovaní na kapitálových trzích. Praha: ASPI, a. s. ISBN: 978- 80-7357-297-6 
https://is.sting.cz/publication/474661?lang=cs

ANNEX

Annex (1) Descriptive Statistics

\begin{tabular}{|l|r|r|r|r|r|}
\hline & \multicolumn{1}{|l|}{ INDEX } & M3 & PE & L & NEER \\
\hline Mean & 8096.396 & 1209013 & 18.72563 & 255708.8 & 107.3665 \\
\hline Median & 7159.405 & 1175023 & 15.22 & 211680.5 & 105.515 \\
\hline Maximum & 19502.65 & 1828169 & 112.24 & 456836 & 124.45 \\
\hline Minimum & 4384.59 & 529188 & 8.9 & 131182 & 96.09 \\
\hline Std. Dev. & 2709.375 & 418941.2 & 13.67579 & 105900.9 & 7.418502 \\
\hline Skewness & 2.025189 & 0.030967 & 4.094683 & 0.620912 & 0.750852 \\
\hline Kurtosis & 7.628462 & 1.676336 & 21.92323 & 1.771713 & 2.517049 \\
\hline CV & 0.334 & 0.347 & 0.730 & 0.414 & 0.069 \\
\hline Jarque-Bera & 223.817 & 10.3892 & 2515.497 & 18.05067 & 14.72278 \\
\hline Probability & 0.00000 & 0.005546 & 0.00000 & 0.00012 & 0.000635 \\
\hline Sum & 1149688 & $1.72 \mathrm{E}+08$ & 2659.04 & 36310649 & 15246.05 \\
\hline Sum Sq. Dev. & $1.04 \mathrm{E}+09$ & $2.47 \mathrm{E}+13$ & 26370.83 & $1.58 \mathrm{E}+12$ & 7759.817 \\
\hline Observations & 142 & 142 & 142 & 142 & 142 \\
\hline
\end{tabular}

Annex (2) Descriptive Statistics of Logarithmic Form

\begin{tabular}{|l|c|c|c|c|c|}
\hline & LOG(INDEX) & LOG(M3) & LOG(PE) & LOG(L) & LOG(NEER) \\
\hline Mean & 8.955757 & 13.93893 & 2.811281 & 12.371 & 4.673947 \\
\hline Median & 8.876178 & 13.9768 & 2.722609 & 12.26272 & 4.658853 \\
\hline Maximum & 9.878306 & 14.41883 & 4.720639 & 13.03208 & 4.823904 \\
\hline Minimum & 8.385851 & 13.1791 & 2.186051 & 11.78434 & 4.565285 \\
\hline Std. Dev. & 0.28093 & 0.377079 & 0.40768 & 0.397523 & 0.067605 \\
\hline Skewness & 1.071118 & -0.39829 & 2.490115 & 0.383668 & 0.651559 \\
\hline Kurtosis & 4.348152 & 1.99968 & 9.783695 & 1.570766 & 2.429629 \\
\hline CV & 0.031 & 0.027 & 0.145 & 0.032 & 0.014 \\
\hline Jarque-Bera & 37.90622 & 9.674842 & 419.0255 & 15.5698 & 11.972 \\
\hline Probability & 0 & 0.007927 & 0 & 0.000416 & 0.002514 \\
\hline Sum & 1271.718 & 1979.329 & 399.2019 & 1756.681 & 663.7005 \\
\hline Sum Sq. Dev. & 11.12794 & 20.04854 & 23.43467 & 22.2815 & 0.644434 \\
\hline Observations & 142 & 142 & 142 & 142 & 142 \\
\hline
\end{tabular}




\section{Annex (3) Cointegration Results}

Date: 08/30/17 Time: 09:54

Sample (adjusted): 2006M01 2017M05

Included observations: 137 after adjustments

Trend assumption: Linear deterministic trend

Series: INDEX M3 L PE NEER

Lags interval (in first differences): 1 to 4

Unrestricted Cointegration Rank Test (Trace)

Hypothesized

No. of CE(s) Eigenvalue

None *

At most $1 *$

At most $2 *$

At most 3

At most 4

\begin{tabular}{r|r} 
& Tra \\
\hline 0.232443 & Stat \\
\hline 0.195248 & \\
\hline 0.119233 & \\
0.08817 & \\
0.008718 & \\
\hline
\end{tabular}

Trace Statistic

\begin{tabular}{|c|c|c|}
\hline & 0.05 & \\
\hline & Critical Value & Prob.** \\
\hline 97.24038 & 69.81889 & 0.0001 \\
\hline 60.99807 & 47.85613 & 0.0018 \\
\hline 31.23878 & 29.79707 & 0.0339 \\
\hline 13.84492 & 15.49471 & 0.0873 \\
\hline 1.199635 & 3.841466 & 0.2734 \\
\hline
\end{tabular}

Trace test indicates 3 cointegrating equation(s) at the 0.05 level

* denotes rejection of the hypothesis at the 0.05 level

**MacKinnon-Haug-Michelis (1999) p-values

\section{Annex (4) Cointegration Results of Logarithmic Form}

Date: 08/30/17 Time: 09:56

Sample (adjusted): 2006M01 2017M05

Included observations: 137 after adjustments

Trend assumption: Linear deterministic trend

Series: LOG(INDEX) LOG(M3) LOG(PE) LOG(L) LOG(NEER)

Lags interval (in first differences): 1 to 4

Unrestricted Cointegration Rank Test (Trace)

Hypothesized

No. of CE(s)

None *

At most $1^{*}$

At most 2 *

At most 3

At most 4

Eigenvalue
0.235884
0.190903
0.146476
0.089953
0.005062

Trace

Trace test indicates 3 cointegrating equation(s) at the 0.05 level

* denotes rejection of the hypothesis at the 0.05 level

${ }^{* *}$ MacKinnon-Haug-Michelis (1999) p-values 


\section{Annex (5) ARDL Cointegrating and Long Run Form}

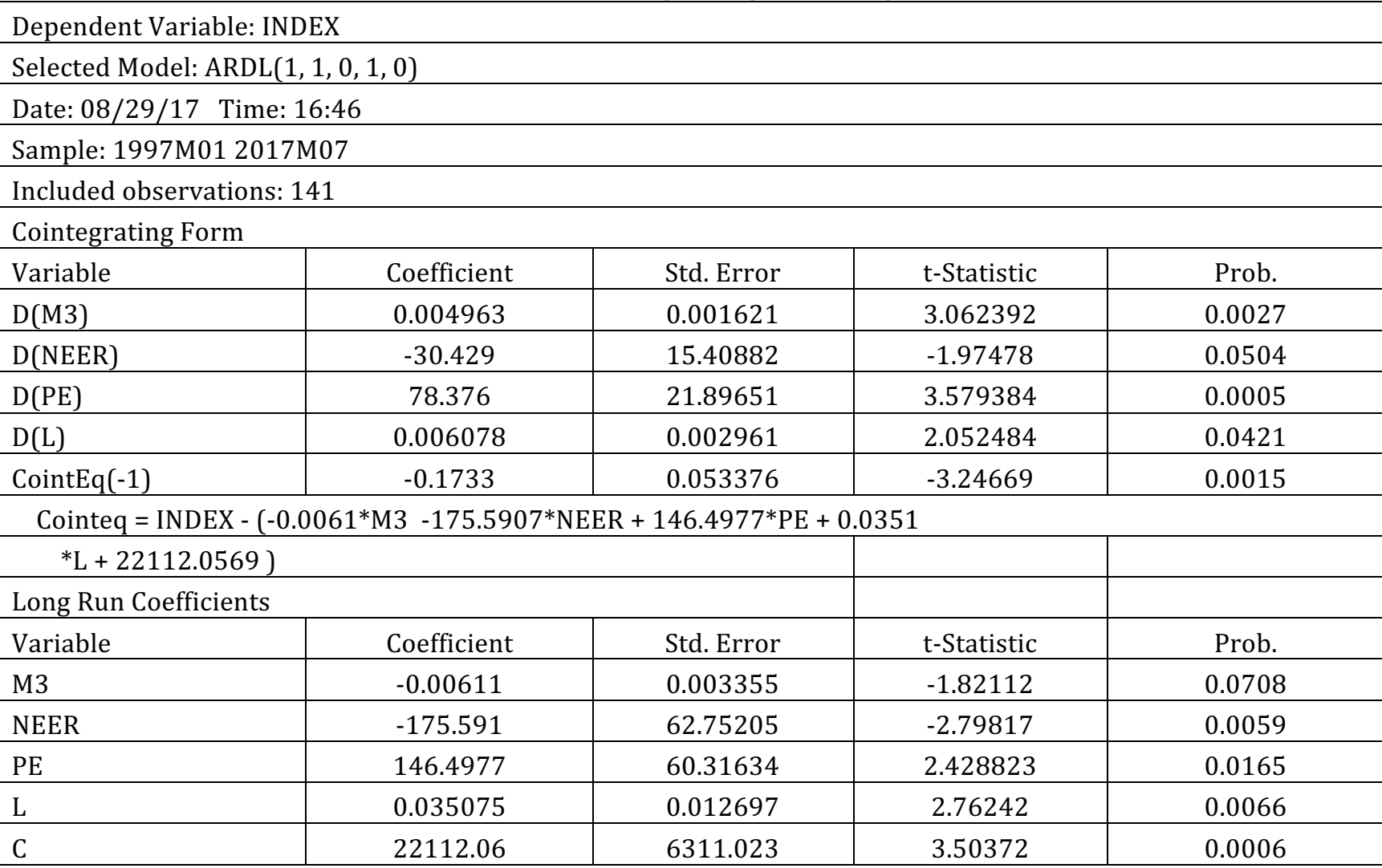

\section{Annex (6) ARDL Cointegrating and Long Run Form (logarithmic Form)}

\begin{tabular}{|c|c|c|c|c|}
\hline \multicolumn{5}{|c|}{ Dependent Variable: LOG(INDEX) } \\
\hline \multicolumn{5}{|c|}{ Selected Model: ARDL $(1,1,0,1,0)$} \\
\hline \multicolumn{5}{|c|}{ Date: $08 / 29 / 17$ Time: $16: 49$} \\
\hline \multicolumn{5}{|c|}{ Sample: 1997M01 2017M07 } \\
\hline \multicolumn{5}{|c|}{ Included observations: 141} \\
\hline \multicolumn{5}{|c|}{ Cointegrating Form } \\
\hline Variable & Coefficient & Std. Error & t-Statistic & Prob. \\
\hline DLOG(M3) & 0.617252 & 0.372377 & 1.657599 & 0.0998 \\
\hline DLOG(NEER) & -0.45713 & 0.171181 & -2.67044 & 0.0085 \\
\hline DLOG(PE) & 0.390678 & 0.082523 & 4.734144 & 0.0000 \\
\hline DLOG(L) & 0.218193 & 0.090456 & 2.412144 & 0.0172 \\
\hline CointEq(-1) & -0.22029 & 0.050085 & -4.39832 & 0.0000 \\
\hline \multicolumn{5}{|c|}{ Cointeq = LOG(INDEX) $-\left(-0.6758^{*}\right.$ LOG(M3) -2.0751*LOG(NEER) + 0.5688} \\
\hline \multicolumn{5}{|c|}{$\left.{ }^{*} \mathrm{LOG}(\mathrm{PE})+0.9905^{*} \mathrm{LOG}(\mathrm{L})+14.1839\right)$} \\
\hline \multicolumn{5}{|c|}{ Long Run Coefficients } \\
\hline Variable & Coefficient & Std. Error & t-Statistic & Prob. \\
\hline LOG(M3) & -0.67582 & 0.307988 & -2.19431 & 0.0299 \\
\hline LOG(NEER) & -2.07512 & 0.56457 & -3.67557 & 0.0003 \\
\hline LOG(PE) & 0.568777 & 0.117965 & 4.821555 & 0.0000 \\
\hline LOG(L) & 0.990479 & 0.287237 & 3.448301 & 0.0008 \\
\hline $\mathrm{C}$ & 14.18386 & 2.931836 & 4.837877 & 0.0000 \\
\hline
\end{tabular}


Annex (7) GARCH Results

\begin{tabular}{|c|c|c|c|c|}
\hline \multicolumn{5}{|c|}{ Dependent Variable: INDEX } \\
\hline \multicolumn{5}{|c|}{ Method: ML ARCH - Normal distribution (BFGS / Marquardt steps) } \\
\hline \multicolumn{5}{|c|}{ Date: 08/29/17 Time: $20: 50$} \\
\hline \multicolumn{5}{|c|}{ Sample (adjusted): 2005M08 2017M05 } \\
\hline \multicolumn{5}{|c|}{ Included observations: 142 after adjustments } \\
\hline \multicolumn{5}{|c|}{ Convergence achieved after 48 iterations } \\
\hline \multicolumn{5}{|c|}{ Coefficient covariance computed using outer product of gradients } \\
\hline \multicolumn{5}{|c|}{ Presample variance: backcast $($ parameter $=0.2$ ) } \\
\hline \multicolumn{5}{|c|}{ GARCH $=\mathrm{C}(6)+\mathrm{C}(7)^{*} \operatorname{RESID}(-1)^{\wedge} 2+\mathrm{C}(8)^{*} \mathrm{GARCH}(-1)$} \\
\hline Variable & Coefficient & Std. Error & z-Statistic & Prob. \\
\hline M3 & 0.003547 & 0.000585 & 6.065386 & 0.0000 \\
\hline $\mathrm{L}$ & 0.001779 & 0.001695 & 1.049852 & 0.2938 \\
\hline $\mathrm{PE}$ & 203.7446 & 10.86658 & 18.74965 & 0.0000 \\
\hline NEER & -8.26953 & 5.17222 & -1.59884 & 0.1099 \\
\hline MA(1) & 0.679839 & 0.090648 & 7.499731 & 0.0000 \\
\hline \multicolumn{5}{|c|}{ Variance Equation } \\
\hline $\mathrm{C}$ & 6630.099 & 3939.352 & 1.683043 & 0.0924 \\
\hline $\operatorname{RESID}(-1)^{\wedge} 2$ & 0.483604 & 0.16292 & 2.968349 & 0.003 \\
\hline $\operatorname{GARCH}(-1)$ & 0.57547 & 0.062336 & 9.231782 & 0 \\
\hline R-squared & 0.70123 & \multicolumn{2}{|c|}{ Mean dependent var } & 8096.396 \\
\hline Adjusted R-squared & 0.692507 & \multicolumn{2}{|c|}{ S.D. dependent var } & 2709.375 \\
\hline S.E. of regression & 1502.405 & \multicolumn{2}{|c|}{ Akaike info criterion } & 16.005 \\
\hline Sum squared resid & $3.09 \mathrm{E}+08$ & \multicolumn{2}{|c|}{ Schwarz criterion } & 16.17152 \\
\hline Log likelihood & -1128.36 & \multicolumn{2}{|c|}{ Hannan-Quinn criterion } & 16.07266 \\
\hline Durbin-Watson stat & 1.686408 & & & \\
\hline Inverted MA Roots & -0.68 & & & \\
\hline
\end{tabular}




\section{Annex (8) GARCH Results of Logarithmic Form}

\begin{tabular}{|c|c|c|c|c|}
\hline \multicolumn{5}{|c|}{ Dependent Variable: LOG(INDEX) } \\
\hline \multicolumn{5}{|c|}{ Method: ML ARCH - Normal distribution (BFGS / Marquardt steps) } \\
\hline \multicolumn{5}{|c|}{ Date: $08 / 29 / 17$ Time: $16: 57$} \\
\hline \multicolumn{5}{|c|}{ Sample (adjusted): 2005M08 2017M05 } \\
\hline \multicolumn{5}{|c|}{ Included observations: 142 after adjustments } \\
\hline \multicolumn{5}{|c|}{ Convergence achieved after 186 iterations } \\
\hline \multicolumn{5}{|c|}{ Coefficient covariance computed using outer product of gradients } \\
\hline \multicolumn{5}{|c|}{ Presample variance: backcast (parameter $=0.2$ ) } \\
\hline \multicolumn{5}{|c|}{ GARCH $=C(7)+C(8)^{*} \operatorname{RESID}(-1)^{\wedge} 2+C(9)^{*} \operatorname{GARCH}(-1)$} \\
\hline Variable & Coefficient & Std. Error & z-Statistic & Prob. \\
\hline LOG(M3) & -0.64093 & 0.10163 & -6.30648 & 0 \\
\hline LOG(PE) & 0.635989 & 0.024586 & 25.86781 & 0 \\
\hline LOG(L) & 0.944861 & 0.083045 & 11.37764 & 0 \\
\hline LOG(NEER) & -1.9797 & 0.1821 & -10.8715 & 0 \\
\hline $\mathrm{C}$ & 13.64842 & 1.049251 & 13.00777 & 0 \\
\hline MA(1) & 0.480089 & 0.106373 & 4.513266 & 0 \\
\hline \multicolumn{5}{|c|}{ Variance Equation } \\
\hline $\mathrm{C}$ & 0.001223 & 0.000608 & 2.013381 & 0.0441 \\
\hline $\operatorname{RESID}(-1)^{\wedge} 2$ & 0.657135 & 0.275018 & 2.389423 & 0.0169 \\
\hline GARCH(-1) & 0.324827 & 0.188016 & 1.727661 & 0.084 \\
\hline R-squared & 0.913224 & \multicolumn{2}{|c|}{ Mean dependent var } & 8.955757 \\
\hline Adjusted R-squared & 0.910034 & \multicolumn{2}{|c|}{ S.D. dependent var } & 0.28093 \\
\hline S.E. of regression & 0.084263 & \multicolumn{2}{|c|}{ Akaike info criterion } & -2.23308 \\
\hline Sum squared resid & 0.965633 & \multicolumn{2}{|c|}{ Schwarz criterion } & -2.04574 \\
\hline Log likelihood & 167.5487 & \multicolumn{2}{|c|}{ Hannan-Quinn criterion } & -2.15695 \\
\hline Durbin-Watson stat & 1.542025 & & & \\
\hline Inverted MA Roots & -0.48 & & & \\
\hline
\end{tabular}

